\title{
BREEDING OF SUNFLOWER RESISTANT TO NEW RACES OF BROOMRAPE (Orobanche cumana Wallr.)
}

\author{
Burlov, V., Burlov, V.
}

The Plant Breeding and Genetics Institute - National Center of Seed and Cultivar Investigation UAAS, Odessa, Ukraine

Received: July 25, 2010

Accepted: November 15, 2010

SUMMARY

The loss of resistance to broomrape by the majority of domestic and foreign hybrids, that are resistant to the $5^{\text {th }}$ race of the parasite $(\mathrm{E})$ in the Black Sea and Azov regions of the country indicates that from about 2004-2005 there appeared new (more virulent) races of the parasite (Orobanche cumana Wallr.). Maternal lines of sunflower hybrids have been developed whose stability to a new race of broomrape is controlled by one dominant gene, $\mathrm{Or}_{6}$. These lines have a high ability of combination on the main economic grounds.

Key words: sunflower, broomrape (Orobanche cumana Wallr.), lines race differentiators

\section{INTRODUCTION}

Broomrape has been known as an extremely dangerous sunflower parasite during the entire history of the commercial cultivation of this important oil crop. The causative agent of this disease is the cross-pollinating plant Orobanche cumana Wallr., which parasitizes the roots of sunflower. Damage caused by the parasite greatly limits the production of this crop in the major regions of its cultivation-Australia, China, Russia, and the southern regions of the European Union.

The first evidence of the harmfulness of broomrape and the successes of breeders, who have created classes of sunflower that are resistant to this parasite, came in 1907 (Beilin, 1965). Later, Satsiperov (1913), who studied samples of sunflower seeds from the Saratov province, described two varieties of folk selection, Armavir and Zelenka, which were almost completely unaffected by broomrape on an infectious background.

The first officially registered varieties of sunflower, Kruglic A-41, Saratovsky 169, Fuksinka 3, Zelenka 10, Chornyanka 35, Krasnodarsky 631 and others,

* Corresponding author 
which were developed by Placek (1930) and Pustovoit, (1939), were resistant to broomrape race A.

Nevertheless, by the end of the 1920's and the early 1930's, almost all of the early varieties of sunflower were so affected by the parasite that in some areas of the North Caucasus, Ukraine, and the Voronezh region sunflower production became unprofitable.

In 1934-1935, academician Zhdanov (1967) created varieties of sunflower such as Zhdanovsky 8281, Zhdanovsky 8835, and others, which resistant not only to broomrape race A but also to a new, more virulent race of the pathogen, race $\mathrm{B}$. Later, similar genotypes were created by Pustovoit (1963) as well. In the prewar and postwar years, the most widespread varieties were Peredovik, VNIIMK 1646, VNIIMK 8931, and Armavir 3497. They were cultivated on more than 3 million hectares of sunflower commodity crops.

In the early 1960s, the so-called Moldovan population of broomrape (race C) affected all industrial varieties that were susceptible to this race (Buhorovich, 1966). By the beginning of 1980's, losses caused by broomrape were the main limiting factor for sunflower production in Romania, Spain, Turkey, Bulgaria, which were known as the main regions for the production of this important oil crop (Aćimović, 1984; Indelen et al., 1983).

By the mid-1980s, researchers who analyzed broomrape seeds collected in Romania and the Danube region near Odessa found five races of the parasite-A, B, C, D, and E (Vranceanu et al., 1980; Burlov, 1988).

Studies in recent years (Pacureanu et al., 2008; Juan Fernandez-Escobar et al., 2008) have shown the occurrence of new (more virulent) races of the parasite $\mathrm{G}$ and $\mathrm{H}$ - in 2000-2007.

The purpose of this study was to compare the virulence of the racial composition of parasite populations collected in Odessa, Turkey, the Priazovskiy region of Rostov, and the Donetzk region of Ukraine and to create resistant sunflower inbred lines and high-yielding hybrid combinations.

\section{MATERIAL AND METHODS}

Broomrape seeds were collected in different regions - the south of the Odessa region (Ukraine), eastern regions of Donetsk district (Ukraine), Azov Steppes of Rostov Region (Russia), and Turkey. Artificial infection of differential lines for broomrape races was carried out in a greenhouse using laboratory-vegetation method developed by Kukin (1960). The percentage of susceptible plants, multiplied by the average number of the parasite nodules, divided by 100 , reveals the infestation degree of self-pollinated lines of sunflower caused by broomrape. In conformity with the actual ratio of plants classes at the studied characteristics (resistance: susceptibility to the parasite) with the theoretically expected was determined 
by the $\chi^{2}$ criteria (Rokitsky, 1973). The agricultural characteristics of hybrids are the result of competitive variety trials. The seed harvest was inspected on plots covering $10 \mathrm{~m}^{2}$ and planted in four replications. The oil content in seeds was determined by a Newport NMR Analyser (Newport Pagnell, England).

\section{RESULTS}

Nowadays, Ukraine sows sunflower on 3.5-4.0 million hectares. The main areas, about $70 \%$ of the total, are concentrated in the south near the Black Sea and Azov steppe regions. These areas of sunflower growth are the most favorable ones for the emergence of new broomrape races. In 2007-2009 some crops in the south of the Odessa region - Bolhrad, Tarutino areas were destroyed by broomrape. A similar situation developed in the Starobeshevo Amvrosiivka area of the Donetsk region in 2009.

Sunflower hybrids resistant to broomrape race E: Zgoda, Od-249 (Odessa), Arena (Syngenta), Reamy, Titanic, NS-H-2017 (Novi Sad), PR-63H80 (Pioneer), etc., are losing their ability to resist the pathogen. This is a sign of the emergence and intensive accumulation of new, more virulent races of the parasite.

Table 1: Reaction of differential sunflower lines for broomrape races to infection by ecologically different populations of the parasite (Odessa 2009-2010).

\begin{tabular}{|c|c|c|c|c|c|c|c|}
\hline \multirow{3}{*}{$\begin{array}{l}\text { Sunflower } \\
\text { genotype }\end{array}$} & \multirow{3}{*}{$\begin{array}{l}\text { Reaction } \\
\text { to the } \\
\text { broom- } \\
\text { rape } \\
\text { races }\end{array}$} & \multicolumn{6}{|c|}{ Source of broomrape } \\
\hline & & \multicolumn{3}{|c|}{ Odessa, Ukraine } & \multicolumn{3}{|c|}{ Donetzk, Ukraine } \\
\hline & & $\begin{array}{l}\text { Number of } \\
\text { infested } \\
\text { sunfl. plants }\end{array}$ & $\begin{array}{l}\text { Susceptible } \\
\text { plants } \\
(\%)\end{array}$ & $\begin{array}{c}\text { Infestation } \\
\text { degree } \\
(\%)\end{array}$ & $\begin{array}{l}\text { Number of } \\
\text { infested } \\
\text { sunfl.plants }\end{array}$ & $\begin{array}{l}\text { Susceptible } \\
\text { plants } \\
(\%)\end{array}$ & $\begin{array}{c}\text { Infestation } \\
\text { degree } \\
(\%)\end{array}$ \\
\hline AD-66 & & 48 & 100.0 & 42.2 & $38^{*}$ & $100.0^{*}$ & $33.6^{\star}$ \\
\hline LC-1003 & $E-A$ & 91 & 52.8 & 1.50 & $58^{*}$ & $3.5^{\star}$ & $0.03^{*}$ \\
\hline LC-1093 & F-A & 82 & 26.8 & 0.58 & $69^{*}$ & $5.8^{*}$ & $0.19 *$ \\
\hline $16 \mathrm{~A} \times 25 / \mathrm{RO}$ & G-A & $29^{*}$ & $3.4^{*}$ & $0.10^{*}$ & $79^{*}$ & $2.5^{\star}$ & $0.11^{*}$ \\
\hline $\mathrm{F}-44$ & & 71 & 15.5 & 0.20 & - & - & - \\
\hline $\mathrm{F}-14$ & & $40^{*}$ & $0^{*}$ & $0^{*}$ & $43^{*}$ & $7.0^{\star}$ & $0.21^{*}$ \\
\hline
\end{tabular}

* results for the year 2010

\begin{tabular}{|c|c|c|c|c|c|c|c|}
\hline \multirow{3}{*}{$\begin{array}{l}\text { Sunflower } \\
\text { genotype }\end{array}$} & \multirow{3}{*}{$\begin{array}{l}\text { Reaction } \\
\text { to the } \\
\text { broom- } \\
\text { rape } \\
\text { races }\end{array}$} & \multicolumn{6}{|c|}{ Source of broomrape } \\
\hline & & \multicolumn{3}{|c|}{ Rostov, Russia } & \multicolumn{3}{|c|}{ Turkish } \\
\hline & & $\begin{array}{l}\text { Number of } \\
\text { infested } \\
\text { sunfl. plants }\end{array}$ & $\begin{array}{l}\text { Susceptible } \\
\text { plants } \\
(\%)\end{array}$ & $\begin{array}{c}\text { Infestation } \\
\text { degree } \\
(\%)\end{array}$ & $\begin{array}{l}\text { Number of } \\
\text { infested } \\
\text { sunfl.plants }\end{array}$ & $\begin{array}{l}\text { Susceptible } \\
\text { plants } \\
(\%)\end{array}$ & $\begin{array}{c}\text { Infestation } \\
\text { degree } \\
(\%)\end{array}$ \\
\hline$A D-66$ & & 19 & 100.0 & 30.2 & 49 & 100.0 & 63.8 \\
\hline LC-1003 & E-A & 85 & 100.0 & 20.5 & 71 & 100.0 & 23.0 \\
\hline LC-1093 & F-A & $54^{*}$ & $33.3^{*}$ & $0.43^{*}$ & 73 & 57.5 & 2.5 \\
\hline $16 \mathrm{~A} \times 25 / \mathrm{RO}$ & G-A & $60^{*}$ & $0^{*}$ & $0^{*}$ & 62.* & $32.2^{\star}$ & $1.03^{*}$ \\
\hline$F-44$ & & 81 & 19.8 & 0.40 & 56 & 16.5 & 0.50 \\
\hline$F-14$ & & $39^{*}$ & $30.8^{\star}$ & $0.88^{*}$ & $50^{\star}$ & $28.6^{\star}$ & $0.66^{\star}$ \\
\hline
\end{tabular}

* results for the year 2010 
Table 1 shows the results of seed parasite infection of plant seedlings sunflower line differentiator's races of broomrape (Orobanche cumana Wallr.). The parasite seed was collected in different regions of Ukraine, Russia, and Turkey.

Reaction of sunflower lines depended on the origin of the Orobanche cumana Wallr. seeds. Thus, plants from the differential line LC-1003, which has the resistance gene $\mathrm{Or}_{5}$ (race E), during the infection with the parasite seeds collected in 2008 in the south of the Odessa region were susceptible up to $52.8 \%$. During the infection with the parasite seeds collected in 2009 in the eastern regions of Donetsk district (Ukraine) they were susceptible up to $3.5 \%$, while the use of seeds collected in the Rostov Region and Turkey resulted in complete susceptibility (100\%).The infestation degree in plants caused by the parasite seeds from the Rostov and Turkish populations was $20.5 \%$ and $23.0 \%$ respectively, whereas with seeds from Odessa and Donetzk, the infestation degree was only $1.5 \%$ and $3.5 \%$, respectively. Such high virulence of E-race parasite populations from the Russian Federation and Turkey can be explained by the intense accumulation of this race due to fields saturation with the sunflower varieties and hybrids susceptible to this race of broomrape.

Despite the fact that the manufacturing share of hybrids that are resistant to broomrape race $\mathrm{E}$ was higher, due to violations of crop rotation the accumulation of race $\mathrm{E}$ was also observed, although it was just half as high (the term of returning to a previous place of sunflower growth instead of the recommended 6-7 years was, at best, 2-3 years).

Reaction of the differential line LC-1093, which has the resistance gene ${ } r_{6}$ (race F), also depended on the origin of the parasite seeds. The portion of susceptible plants in the case of infection with the seeds collected in the Odessa and Donetzk region was up to $26.8 \%$ and $5.8 \%$, respectively, whereas plants infected with the seeds from the Rostov population had a susceptibility level of $33.3 \%$. Broomrape seeds from Turkey caused a susceptibility level of $57.5 \%$, and the infestation degree was $2.5 \%$.

The results of the testing of the line- $16 \mathrm{~A} \times 25 \mathrm{RO}$ used as the differential for race $\mathrm{G}$, which was conducted in 2010 , showed that the plants of this line infected with seeds of broomrape collected in Odessa and Rostov regions were affected up to $3.4 \%$ and $2.5 \%$, respectively. Among the 60 plants of $16 \mathrm{~A} \times 25 \mathrm{RO}$ analyzed that were infected with broomrape seeds from the Rostov region, no affected plants were observed, while among the plants of this line infected with broomrape seeds collected in Turkey the percentage of plants affected was $32.2 \%$.

Analyzing the above results, it can be concluded that there are more virulent $\mathrm{G}$ and $\mathrm{H}$ races of the parasite in populations of broomrape collected in four regions. The highest share of $\mathrm{G}$ race is in the Turkish population (32.2\%), while the shares in the Odessa and Donetsk are significantly lower (3.4\% and $2.5 \%$, respectively). The race is not found in the Rostov population. Perhaps the use of sunflower hybrids resistance to new races intensifies the emergence of more virulent races of the parasite. 
In the case of differential lines for broomrape races $\mathrm{E}$ and $\mathrm{F}$, by contrast, the reaction of resistance of the precocious maternal lines of sunflower (F-44B) to different parasite races did not depend on the origin of broomrape seeds. The share of affected plants that were infected with the seeds of Turkish population (high concentration of $\mathrm{F}$ and $\mathrm{G}$ race) was $16.5 \%$, while for Rostov and Odessa the shares were $19.8 \%$ and $15.5 \%$, respectively.

Among the plants of the F-14 line infected with seeds of broomrape gathered in the Odessa region, no susceptible plants were found, whereas among the plants infected with seeds from the Donetsk region, the percentage of susceptible plants was $7 \%$. As for Rostov and Turkey, the susceptibility levels were $30.8 \%$ and $28.6 \%$, respectively. According to our findings (Burlov, 1988) and the latest Romanian research (Pacureanu et al., 2008), the genetic nature of sunflower resistance to the broomrape pathogen is of oligogene character: the resistance to the new (more virulent) races is controlled by one dominant gene and provides resistance to all previously identified races. Following these facts, it is logical to assume that resistance to the new broomrape race $\mathrm{F}$ from the parental line $\mathrm{F}-44 \mathrm{~B}$ (as well as other lines from future hybrids of Odessa selection) is controlled by one dominant gene - $\mathrm{Or}_{6}$.

The results in Table 2 confirm that the resistance of the line $\mathrm{F}-44 \mathrm{~B}$, which is heterozygous for this character, is controlled by one dominant gene, $\mathrm{Or}_{6}$, and does not depend on the origin of the infection. Moreover, if we assume the presence in these populations (especially the Turkish one) of the more virulent race $\mathrm{G}$, this gene may be $\mathrm{Or}_{7}$.

Table 2: The nature of inheritance of resistance of sunflower lines to broomrape race $\mathrm{F}$, (Odessa 2007-2009)

\begin{tabular}{|c|c|c|c|c|c|c|c|}
\hline \multirow{2}{*}{ Line } & \multirow{2}{*}{ Generation } & \multirow{2}{*}{$\begin{array}{c}\text { Source of } \\
\text { broomrape }\end{array}$} & \multicolumn{2}{|c|}{ Number of plants } & \multirow{2}{*}{$\begin{array}{c}\text { Expected } \\
\text { ratio }\end{array}$} & \multirow{2}{*}{$\chi^{2}$} & \multirow{2}{*}{$\mathrm{P}$} \\
\hline & & & resistant & susceptible & & & \\
\hline F-44B & $\mathrm{S}_{2}$ & Turkey & 56 & 11 & $3: 1$ & 2.63 & $0.10 \div 0.25$ \\
\hline$F-44 B$ & $\mathrm{~S}_{2}$ & Rostov & 65 & 16 & $3: 1$ & 1.16 & $0.25 \div 0.50$ \\
\hline$F-44 B$ & $\mathrm{~S}_{2}$ & Odessa & 60 & 11 & $3: 1$ & 3.38 & $0.05 \div 0.10$ \\
\hline$F-78 B$ & $\mathrm{~S}_{2}{ }^{*}$ & Odessa & 14 & 6 & $3: 1$ & 0.28 & $0.50 \div 0.75$ \\
\hline$F-78 A$ & $\mathrm{BC}_{1}{ }^{*}$ & Odessa & 9 & 12 & $1: 1$ & 0.42 & $0.50 \div 0.75$ \\
\hline$F-78 B$ & $\mathrm{~S}_{3}$ & Odessa & 27 & 0 & & & \\
\hline$F-78 A$ & $\mathrm{BC}_{2}$ & Odessa & 27 & 0 & & & \\
\hline F-34B & $\mathrm{S}_{2}^{*}$ & Odessa & 14 & 4 & $3: 1$ & 0.08 & $0.75 \div 0.90$ \\
\hline$F-34 A$ & $\mathrm{BC}_{1}{ }^{*}$ & Odessa & 7 & 8 & $1: 1$ & 0.06 & $0.75 \div 0.90$ \\
\hline F-34B & $\mathrm{S}_{3}$ & Odessa & 17 & 0 & & & \\
\hline$F-34 A$ & $\mathrm{BC}_{2}$ & Odessa & 19 & 0 & & & \\
\hline $\mathrm{F}-14 \mathrm{~B}$ & $\mathrm{~S}_{2}^{*}$ & Odessa & 16 & 4 & $3: 1$ & 0.27 & $0.50 \div 0.75$ \\
\hline$F-14 A$ & $\mathrm{BC}_{1}{ }^{*}$ & Odessa & 10 & 9 & $1: 1$ & 0.06 & $0.75 \div 0.90$ \\
\hline$F-14 B$ & $\mathrm{~S}_{3}$ & Odessa & 16 & 0 & & & \\
\hline $\mathrm{F}-14 \mathrm{~A}$ & $\mathrm{BC}_{2}$ & Odessa & 18 & 0 & & & \\
\hline
\end{tabular}

* Results of experiments in 2007 
Parental lines of commercial hybrids in our selection (F-78, F-34 and F-14) have genetically determined resistance to broomrape race $\mathrm{F}$, which came from the Odessa parasite population (Table 2). The actual splitting to the studied classes (resistant/receptive) of all descendants from self-pollinated lines and the backcrosses in 2007 matched the theoretically expected ratios of 3:1 and 1:1. During the analysis of descendants from plant crossings of 2008, we selected genotypes of these lines (sterile analogues and sterility fixers) that are homozygous with respect to the trait of resistance to broomrape race $\mathrm{F}$.

Effective selection of parental lines that are resistant to the new highly virulent broomrape races $(\mathrm{F}, \mathrm{G})$ provided an opportunity for the creation and use of resistant hybrids. However, the sunflower production in the southern regions is limited by broomrape, and in the central forest-steppe there is a significant (20\%) lesion of culture caused by new virulent races of downy mildew (Plasmopara halstedii Berl.). Recent studies of the Plant Breeding and Genetics Institute, Odessa scientists (Burlov and Babayants, 2005; Burlov, 2007) that were devoted to the study of the racial structure of the parasite population from Odessa have contributed to the creation of male lines that can restore pollen fertility (A-83455, AIS-51, AC-70165) and are resistant to the new races of downy mildew: 710 and 730 . These steps have led to the development of advanced sunflower hybrids (Table 3 ) with a group resistant to the exciters of broomrape and downy mildew.

Table 3: Basic commercial characters of sunflower hybrids with group resistance to the causative agents of broomrape (F-race) and downy mildew (race 710, 730), (Odessa, 2008).

\begin{tabular}{lccccccc}
\hline $\begin{array}{l}\text { Hybrid } \\
\text { combination }\end{array}$ & $\begin{array}{c}\text { Days to } \\
\text { flowering }\end{array}$ & $\begin{array}{c}\text { Seed } \\
\text { moisture }\end{array}$ & \multicolumn{2}{c}{$\begin{array}{c}\text { Seed yield } \\
\text { + to standard }\end{array}$} & Oil content & $\begin{array}{r}\text { Oil yield (0\% moisture.) } \\
\text { + to standard }\end{array}$ \\
\cline { 2 - 9 } & days & $\%$ & t/ha & t/ha & $\%$ & t/ha & t/ha \\
\hline F14/A83455 & 59 & 9.5 & 2.92 & 0.52 & 55.2 & 1.46 & 0.38 \\
F34/×1008** & 55 & 7.8 & 2.95 & 0.31 & 55.8 & 1.52 & 0.26 \\
F78/AIS51 & 59 & 8.8 & 3.33 & 0.56 & 52.4 & 1.59 & 0.23 \\
F14/AC70165 & 61 & 8.2 & 3.20 & 0.43 & 55.3 & 1.59 & 0.23 \\
LSD $_{0,05}$ & & & & $0.29 \div 0.33$ & & & $0.11 \div 0.15$ \\
\hline
\end{tabular}

* standard - F14/103

** - Joint - Odessa/Kharkiv hybrid

As a result of breeding trials in 2008 the hybrid combinations F14/A83455 and F78/AIS51 exceeded the standard F14/AC70165 (which is similar to the best disease resistance hybrid) in the yield of seeds, respectively, at $0.52 \mathrm{t} / \mathrm{ha}$ and $0.56 \mathrm{t} / \mathrm{ha}$ with seed oil content of $55.2 \%$ and $52.4 \%$, oil yield, respectively, 0.38 and 0.3 t/ha. 


\section{CONCLUSIONS}

Summarizing the results presented in this work, the following can be said:

- the racial structure of the studied Odessa, Donetzk, Rostov and Turkish populations of broomrape (Orobanche cumana Wallr.) includes the new virulent races $\mathrm{F}$ and $\mathrm{G}$ and, possibly, race $\mathrm{H}$ as well (especially the Turkish population of the parasite);

- the created parental lines have resistance to broomrape because of the genes $\mathrm{Or}_{6}$ and $\mathrm{Or}_{7}$, which control their resistance to the new races $\mathrm{F}$ and $\mathrm{G}$;

- new promising high-yielding sunflower hybrids have group resistance to new races of broomrape ( $\mathrm{F}$ and $\mathrm{G}$ ) and downy mildew races 710 and 730 .

\section{REFERENCES}

Aćimović, M., 1984. Sunflower diseases in Europe, the United States and Australia, 1981-1983. Helia 7: 45-44.

Fernández-Escobar, J., Rodríguez-Ojeda, M.I. and Alonso, L.C., 2008. Distribution and dissemination of sunflower broomrape (Orobanche cumana Wallr.) race $\mathrm{F}$ in Southern Spain. In: Velasco, L. [ed.], Proc $17^{\text {th }}$ Intl. Sunflower Conf., Cordoba, Spain, 8-12 June 2008. Intl. Sunflower Assoc., Paris, France 1: 231-236.

Indelen, E., Vluderc, A.O., Kiral, B., Salihoglu, M. and Tunali, R., 1983. Evaluation of some sunflower genotypes for resistance to Orobanche cumana Wallr., in Turkey. Helia 6: 2728.

Pacureanu, M.J., Raranciuc, S., Procopovici, E., Sava, E. and Nastase, D., 2008. The impact of the new races of broomrape (Orobanche cumana Wallr.) parasite in sunflower crop in Romania. In: Velasco, L. [ed.], Proc $17^{\text {th }}$ Intl. Sunflower Conf., Cordoba, Spain, 8-12 June 2008. Intl. Sunflower Assoc., Paris, France 1: 225-229.

Vranceanu, A.V., Tudor, V.A., Stoenescu, F.M. and Pirvu, N., 1980. Virulence groups of Orobanche cumana Wallr., differential hosts and resistance sources and gens in sunflower. In: Proc. $9^{\text {th }}$ Intl. Sunflower Conf., Torremolinos, Spain, 8-13 July 1980. Intl. Sunflower Assoc., Paris, France 1: 74-82.

Бейлин, И.Г., 1965. К истории вопроса о создании сортов подсолнечника, устойчивых против заразихи и ржавчины. Тезисы докладов IV Всесоюзном совещании по иммунитету с.х. растений.- Кишинев: Парт. изд-во ЦК КП Молдавии. С.166.

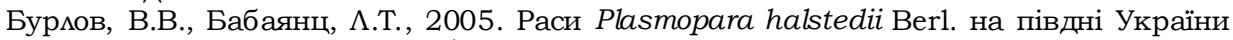
та ефективність до них $P l$ генів. Селекція і насінництво, Вип.90. Харків. С. 157161.

Бурлов, В.В., 1988. Вирулентность одесской популяции заразихи (Orobanche cumana Wallr.) и характер наследования устойчивости подсолнечника к паразиту. Прикладные аспекты генетики, цитологии и биотехнологии с.х. растений. Сборник научных трудов СГИ., Одесса. С. 36-45.

Бурлов, В.В., Бурлов, В.В., 2007. Успадкування стійкості нових міній соняшника до 730 раси НБР (Plasmopara helianthi Novot.), та вплив гена $P l_{6}$ на основні господарські ознаки гібридів соняшника. Досягнення і проблеми генетики, селекції та біотехнології, Т2, Київ, Аогос. С. 40-44.

Бухорович, П.Г., 1966. Изучение вирулентности заразихи разного происхождения и устойчивость к ней ряда сортов подсолнечника. Сборник работ по масличным культурам. Краснодарское книж. изд-во., Вып. 3. С. 22.

Жданов, А.А., 1967. Итоги селекционной работы по масличным культурам на Дону. Достижения отечественной селекции. М.: Колос. С. 231-242.

Кукин, В.Ф., 1960. Методы оценки подсолнечника на устойчивость к заразихе. Защита растений от вредителей и болезней. №7: С. 39.

Плачек, Е.М., 1930. Проблема селекции подсолнечника. Тр. Всесоюзного съезда по генетике, селекции, семеноводству и племенному животноводству. - $\Lambda .:$ Изд-во редкоммегии съезда. - Т4. 
Пустовойт, В.С., 1939. Селекция подсолнечника. Агротехника и селекция масличных культур, М. С. 75-87.

Пустовойт, В.С., Пустовойт Г.В., 1963. Селекция подсомнечника на устойчивость к заразихе Защита растений от вредителей и болезней. №4: С. 15-17.

Рокицкий, П.Ф., 1973. Изучение степени соответствия фактических данных теоретически ожидаемым. Биологическая статистика. Минск. С. 239-260.

Сациперов, Ф.А., 1913. Устойчивость панцирных сортов подсолнечника против заразихи. Тр. Бюро по прикл. ботанике. Т9: С 251. 